itself to him, at least as an individual, as an unalterable order of

things in which he must live.

-MAX WEBER ${ }^{1}$

\title{
Stock Market Populism Investment Clubs and Economic History
}

“Irrational Exuberance"

Much that can be said about the spirit of the 1990s in America can be encapsulated in the publication of three books in rapid succession between May and September 1999: Dow 36,000; Dow 40,000; and Dow 100,000. Issued by three different publishers, and written by three different sets of authors, each book vied to be the most optimistic about the upward trajectory of U.S. stocks. Though we might now wish to shelve these books in the science fiction section of the library, at the time their ideas were treated quite seriously and discussed earnestly in almost every public news forum you could name. In 1999, everyone agreed that the sky was the limit for the American stock market: the only question worth asking was, how high is the sky?

However implausible their optimism might seem in the morning-after light of the early twenty-first century, these books simply reflected the astonishing events occurring immediately before and after their publication. On March 29, 1999, the Dow Jones Industrial Average-a group of stocks issued by thirty industrial firms, which have long been used by the Dow Jones Corporation as a barometer of the U.S. stock market as a wholeclosed above 10,000 for the first time in its history, having doubled its value since 1995. During the five weeks that followed this benchmark, the Dow climbed another 1,000 points-the fastest run-up in its history-and 
closed over 11,000 on May 3. This orgy of economic optimism culminated on January 14, 2000, when the Dow closed at what was then an all-time high of $11,722.98$, followed by a descent almost as swift as its rise, with the index dropping almost 3,000 points in a few months. Despite the dramatic changes in the numbers, some aspects of the market boom of the late 1990s are still very much with us.

Among the most notable legacies of this extraordinary period is the shift in what could be called the "investor class." Once limited to a tiny elite among America's wealthiest families-the 1 percent of adults who owned stocks in 1900, which by 1952 had risen to just 4 percent-investing in stocks became a mass activity, involving over half the U.S. adult population by the end of the twentieth century. ${ }^{2}$ Much of this growth in "market populism" occurred during the 1990s. For example, at the beginning of that decade, about 21 percent of American adults owned stocks; seven years later, the percentage had more than doubled, rising to 43 percent; by 1999 , the figure was 53 percent. The last time the number of investors doubled in America, the change took twenty-five years: from 10 percent in 1965 to 21 percent in $1990 .^{3}$

This shift in the composition of the "investor class" brought with it substantial demographic and political changes. For example, while women made up a little less than a third of American investors in 1990, they constituted fully half of the "investor class" by 1999. In addition, by 1998 the majority of the nation's registered voters were also investors, spurring declarations of a major political shift in America, with the New York Times announcing the birth of "shareholder democracy." The views of the nation's newspaper of record on this subject capture the expansive spirit of the era: "This may be the least appreciated economic, cultural and political development in recent years ... we have developed a mass culture of investing, the first to exist anywhere in the world. American democratic capitalism has brought about the democratization of capitalism."

Americans flocked to the stock market as they once flocked to lands of opportunity. And despite the market downturn, this "new investor class" appears to have continued investing, unlike the generation that followed the crash of 1929. How did this change occur, and what does it mean socially and economically?

It is significant that the initial research for this book took the form of an ethnography conducted in the Silicon Valley. Like the populist expansion of the nineteenth century, the stock market boom turned Americans' attention westward, toward the 1,500-square-mile area bounded by San Mateo to the north, Gilroy to the south, Fremont to the east, and the Pacific coast on the western edge. An area formerly known as the plum- and apricot- 
growing capital of California, the Silicon Valley was so entirely transformed by the mid-1990s that it surpassed Detroit as the nation's leading export region. ${ }^{5}$ The transition was swift and dramatic. Between 1994 and 1998, thousands of people moved to the area every month to work in high-tech jobs, creating the kind of traffic jams that northern Californians had previously associated with Los Angeles. These material changes were accompanied by hyperbolic rhetoric that proclaimed, the end of the old worldeconomically and even socially-and rise of an entirely new regime in which none of the conventional wisdom applied and the rules would be made by smart young men and their machines. ${ }^{6}$ Among the first casualties of this revolution were the metrics used to value companies. In the new order, anything that smacked of "bricks and mortar" was deemed useless: what counted was ideas. That meant that companies' value would no longer be assessed by whether they made a profit, or even made a product; anything with dot.com after the company name was held to be a good bet. A best-selling book of the time proclaimed, "The old rules are broken ... Forget supply and demand ... Old business know-how means nothing."

Anyone who paid attention at that time recalls the strangely manic tenor of public dialogue about economic conditions. It resembled nothing so much as a very long infomercial, complete with hagiographic rags-toriches stories featuring leading entrepreneurs, such as Steve Jobs and Steve Wozniak of Apple Computer. Economist Paul Krugman described the rhetoric of the "new economy" as "a rapid-fire blur of neologisms and breathless declarations that all the rules have changed, that there are limitless opportunities for those who have the courage to let go of old assumptions." "At the same time, skepticism about the "new economy" was so marginalized that it could scarcely bear public discussion, except under the guise of humor-the traditional method for treating many taboo subjects. For instance, in July 1997, the Wall Street Journal ran a front-page story quoting an investor who said that the notoriously bearish investment newsletter Grant's Interest Rate Observer was now worth reading only for entertainment value: "It's like [reading] the Marquis de Sade; it's interesting as long as you don't try to do it."

To study investor behavior at this time and place was a bit like studying government in 1789 Paris. Investing was exciting, confusing, and tumultuous - and the only game worth playing. People who at another point in history might have joined a temperance league or a fraternal organization instead joined investment clubs, drawn by the recognition that the economy was where the action was, historically and culturally. Though some of these individuals seemingly had little economic need to invest, the president of one group spoke for many people in my study by explaining that 
she had joined an investment club because she was "caught up in the euphoria of the bull market." Of course, investing is driven by the profit motive, as will be discussed at greater length in subsequent chapters. But investing together during the 1990s also meant participating in a form of social organization that was both historically specific and status-relevant: in other words, fashionable.

At the height of the bull market, between late 1997 and early 1999, I studied seven Silicon Valley investment clubs, attending their monthly meetings over the course of a year and supplementing my observations of their decision-making behavior with in-depth interviews. (See this chapter's appendix for further details on sample selection and methodology.) Investment clubs, often characterized as "do-it-yourself mutual funds," are voluntary associations of ten to fifteen people who pool their money to invest in the stock market. Based on what I learned from my observations and interviews, I gathered survey data from 1,245 investment clubs and over 11,000 individuals nationally, with results I report in subsequent chapters.

Although investment clubs have existed in the United States for at least a century, they did not become extremely popular until the 1990s, when they constituted the major vehicle of the "popular finance" movement that has attracted so much attention from the media and policy makers. Through the clubs, an estimated 11 percent of the U.S. population collectively poured hundreds of millions of dollars into the stock market. ${ }^{10}$ In addition, investment club participants during that period captured a broadly representative slice of the U.S. population, particularly groups that have previously been underrepresented in studies of investor behavior, including the very young, the elderly, and women. Approximately 60 percent of investment club members are women, and there is wide variation in age and occupational status, with members ranging from teenagers to octogenarians, and from executives to farmworkers. ${ }^{11}$ Thus, what started as an investigation of the social underpinnings of investor behavior turned into something larger: a snapshot of historical and social transition, as millions of people were caught up in what Federal Reserve chairman Alan Greenspan called "irrational exuberance."

\section{A Brief History of the Investment Club Phenomenon}

Investment clubs make such useful research settings for studying real-life investor behavior that it is surprising that they were virtually ignored until this research was conducted in the late 1990s. The first U.S. investment 
club was founded in Texas in 1898, based on a European model going back several generations. ${ }^{12}$ But the clubs were little more than an obscure hobbyist movement until the closing years of the twentieth century, when the stock market began its record-breaking upward surge and ordinary Americans rushed to participate in the boom.

Investment clubs were at the epicenter of this economic and social transformation. With each market surge, NAIC enrollments swelledpeaking in 1998 at 37,129 member clubs-as did the involvement of women. As a benchmark, NAIC's 1986 membership data show that allwomen's clubs made up 38 percent of NAIC enrollments, followed by 35 percent mixed clubs and 27 percent all-men's clubs. Ten years later, mixed clubs made up 47 percent of NAIC membership, followed by 41 percent all-women's clubs; meanwhile, all-male clubs had fallen to a mere 12 percent of enrollments. Five years later, the trend had continued further in the same direction, with all-women's clubs representing 54 percent of the total NAIC enrollments, mixed clubs 38 percent, and all-men's clubs only 8 percent. Overall, the balance shifted through the massive entry of women into investing; once a minority, women comprised 62 percent of NAIC membership by 2001 .

Fluctuation in investment club participation has been influenced not only by economic imperatives but also by cultural and historical conditions. For example, the 1950s witnessed a push to woo back to the stock market a generation scared away from investing by the 1929 crash. Corporations, stock exchanges, and brokerage firms urged Americans to purchase stock though a joint education/public relations campaign titled "People's Capitalism." Charles Merrill, founder of Merrill-Lynch, made his fortune by advertising extensively to individual investors and by publishing newsletters encouraging Americans to get involved in the stock market. Another pioneer of market democratization-George Funston, who become president of the New York Stock Exchange in 1951-leveraged the anticommunist sentiment of the time to claim that buying common stock was a vote for democracy and the American way. ${ }^{13}$ The perennial appeal of the "investor as patriot" metaphor was reaffirmed fifty years later by the numerous e-mails that crisscrossed the nation following the September 11 attacks, urging Americans to buy stocks to prop up the faltering economy and signal defiant confidence in the face of the terrorism that had targeted the nation's financial center. ${ }^{14}$

For investment clubs, this link between investing and American identity is captured by NAIC's slogan: "Own Your Share of America." This demotic strain in the U.S. stock market is more than a marketing ploy: there seems to be a genuine sense of Manifest Destiny among American 
investors, characterized by belief in limitless possibilities for expansion, and the average citizen's entitlement to a piece of the economic pie. It is remarkable how readily this set of beliefs translated from the landgrabs of the 1840 s to the stock market of the 1990s. As one historian put it, "the essence of speculation remains a Utopian yearning for freedom and equality which counterbalances the drab rationalistic materialism of the modern economic system." ${ }^{\prime 5}$

Since investment clubs have served as the primary point of entry for new investors into the stock market, it is not surprising that club enrollments have risen and fallen with waves of confidence in the market. Figure 1.1 compares NAIC's club enrollments with the Dow Jones Industrial Average since NAIC began keeping records in 1952 . The trend lines match very closely, although most changes in club enrollments lag major market swings by several years. For example, investment club participation peaked first in 1962, with just over 106,000 members, following the nearly 20 percent surge in the Dow Jones Industrial Average between 1959 and 1960. The second peak in investment club participation occurred in 1970, with 169,000 members enrolled, about four years after a record high in the stock market. The decline in club enrollments began in the early 1970s as Vietnam, Watergate, and the energy crisis erased fifteen years' worth of gains in the Dow. However, the lowest enrollment levels (44,000 individual

Figure 1.1

NAIC club enrollment versus stock market growth, 1952-2005

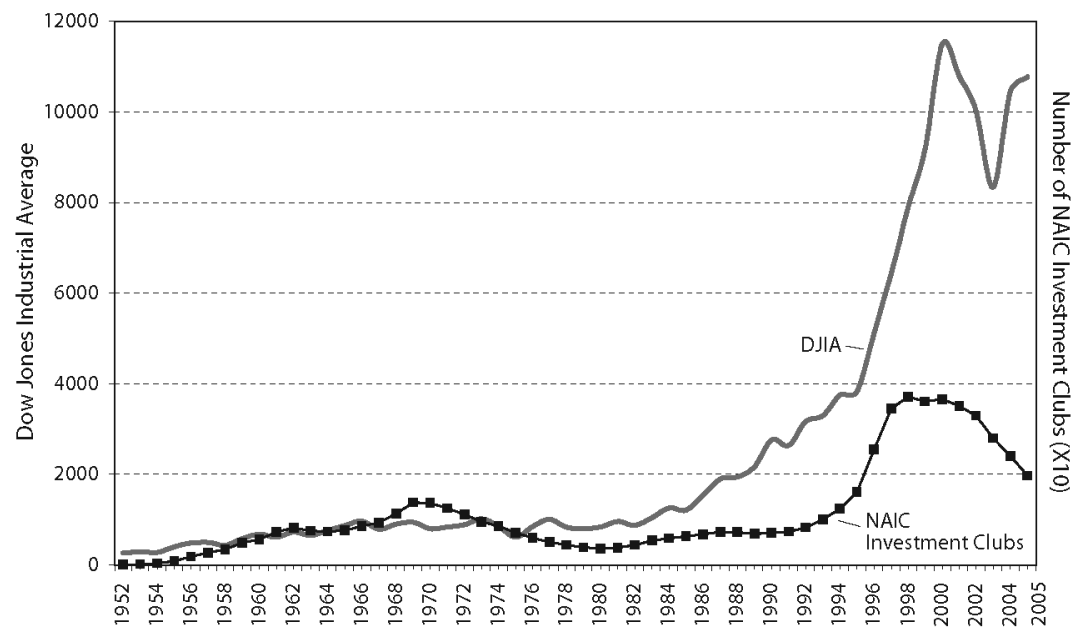


members-fewer than the 1958 membership numbers) occurred in 1980, five years after the Dow hit its lowest point.

The Dow had regained all its lost ground by 1983, but investment club enrollments did not return to 1970 levels until 1994, when membership began soaring with the onset of the bull market; enrollment reached a peak of over 600,000 individual members between 1998 and 1999. The pattern breaks down somewhat during the period from 1999 to 2001, when there was a steep plunge in investment club participation; this may have been occasioned by the decline of the high-technology boom. Although the Dow has certainly represented a large segment of the American investment market historically, the late 1990s were dominated by the high-technology stocks listed on the NASDAQ exchange. As the high-technology boom wound down in 2001, investment club enrollments began to track the Dow more closely.

From the highs of "irrational exuberance"-marked by peaks in the early 1970s and mid-1990s - to the long period of aversion to the stock market in the intervening twenty-five years, the history of investment club enrollments echoes recent findings that individual investors do not just react to market conditions-they overreact, often wildly. ${ }^{16}$

\section{Economic, Legal, and Technological Factors}

The investment club "renaissance" of the 1990s was not due just to the upswing in the stock market during that period. More importantly, as noted in the previous chapter, new kinds of investors entered the stock market. Women and people of color, after years of being the tiniest of minorities in investing, joined the "investor class" en masse. Thus, investment clubs rose from the ashes of stagflation with a push from new kinds of investors forming new clubs, rather than building on old ones. This was part of a larger trend toward broadening the demographic composition of the investor population.

The popularization of investing and investment clubs in the United States during the 1990s was facilitated by several organizational and technological developments, most notably that of discount brokerage firms and the World Wide Web. While investment clubs have been available as an organizational form for some time, the innovations of the past decade made it possible to invest efficiently as a club. Specifically, changes in organizations and technology lowered the transaction costs that once made investing prohibitively expensive for all but the very wealthiest Americans. 
The essence of this efficiency was the diminishing importance of brokers, who prior to the 1980s served as the sole gatekeepers of the stock market. Establishing a relationship with a brokerage firm was difficult, if not impossible, for anyone but the wealthy due to the commission system. The advent of discount brokerage firms in the 1980s created an opening in the opportunity structure of investing; commissions were lowered, and small traders found a niche. But discount brokers were able to cut commissions in part because they did not give investing advice like their fullservice counterparts. Thus, the low-cost route was open only to relatively sophisticated investors. The most serious blow in favor of popularization of the stock market was finally struck by the World Wide Web. By the mid1990s anyone with Internet access could download sophisticated investment information and execute trades.

These developments intersected nicely with NAIC's model of lowering the barriers to entry into the stock market by spreading out the financial risk and the research burden of investing among the members of clubs. In addition, NAIC provides investment ideas (via a monthly magazine, Better Investing), training courses in investment analysis, and deeply discounted brokerage services. As of 2000 , clubs were paying $\$ 40$ per year for NAIC services-a relative bargain, given that the average cost of a single share of stock on the New York Stock Exchange is about \$35.

To permit maximum dissemination of its populist investing message, NAIC boiled its educational strategy down to four principles:

1. Invest regularly regardless of market outlook.

2. Reinvest all earnings from investments.

3. Invest in growth firms. ${ }^{17}$

4. Diversify to reduce risk.

Within these constraints, NAIC recommends that investors evaluate stocks based on two basic measures: "reasonable price" and "management capability" - the ability of management to ensure a minimum 15 percent annual growth rate. The overall approach is analytical and conservative. In fact, this general strategy-originally developed by Benjamin Graham in the 1930s-is known in financial circles as the "fundamentalist" approach to the market. ${ }^{18}$ Thus, while investing in stocks always carries risks, the NAIC method offers little in the way of the excitement associated with day traders and get-rich-quick schemes. People who are interested in high-risk, high-profit investing generally do not join investment clubs. Even in clubs that adhere loosely or not at all to NAIC principles, the group format and monthly meetings present substantial constraints to action: it is difficult to make a quick profit when decisions can only be made every four to five 
weeks, and must be approved by fifteen other people. This may explain part of NAIC's appeal to middle-aged women; studies of risk and financial decisions indicate that women and people in midlife are more conservative than men or people in other age groups, respectively. ${ }^{19}$

Even though investing was easier than ever in the 1990s-between NAIC's low-risk and easy-to-follow investment strategies and the low financial and technical barriers to entry-it still remains to be explained why investment clubs became so popular. The presence of an attractive opportunity does not in itself explain how millions of Americans came to be involved in investing. I argue that the surge of new investors-investment clubs in particular-during the 1990s was due in large part to the changing social contract between labor and management, which made investing an increasingly necessary source of income.

Between 1985 and 1995, three economic changes altered the conditions of American workers, pushing them toward the stock market:

- The number of workers participating in $401(\mathrm{k})$ and other definedcontribution retirement plans tripled.

- Real wages declined. ${ }^{20}$

- Corporate after-tax profits tripled.

Taken together, these three changes put a majority of Americans in the position of having to make up wages and benefits-particularly retirement benefits-through their own efforts. The stock market, with its historical returns of 11 percent annually, provided one of the few places to make up the shortfall.

The change in retirement benefits is particularly significant because it affected so many jobs, and because the issue of retirement planning became suddenly urgent as the baby boom generation entered middle age. NAIC's survey data indicate that retirement savings have historically been the primary objective of 80 percent of investment club members. A huge demographic shift made retirement, and the necessity for investment, an increasingly real and urgent prospect.

Until the late 1970s, most American workers could expect to receive traditional pensions-known as "defined benefit" plans-upon retirement. Under this regime, employers took full responsibility for setting aside and managing employees' retirement funds. But after the laws governing private pension plans changed in the mid-1970s, employers began shifting the risk and responsibility of retirement savings to employees. Out of this change emerged the so-called "defined contribution" plan-the most common of which is the $401(\mathrm{k})$ - in which employees must decide 
for themselves how much money to deduct from their salaries and how it should be invested.

The change was rather sudden for such an institutionalized aspect of the American employment system. The U.S. Census Bureau (1996) reports that between 1980 and 1992 the number of "defined benefit" (traditional pension) plans decreased by more than half, while the number of $401(\mathrm{k})$ and other "defined contribution" plans more than doubled. As of 1994, fourteen million Americans were actively participating in 401(k) plans. ${ }^{21}$ More importantly, 52 percent of U.S. workers wound up with no corporate retirement benefits at all. ${ }^{22}$ Even the safety net of last resort-Social Security-may be subject to the risks of the stock market if the current presidential administration has its way. ${ }^{23}$ This has created a new imperative for individuals to become informed about investing and financial planning.

Concurrent with the growing uncertainty of retirement benefits, real wages declined as firms diverted a bigger share of revenues from wages to profits. This period was also characterized by "downsizing" of the workforce. By keeping labor costs down, profits stayed high. But for workers, this meant that employment and retirement became a great deal less secure, with risks that had once been the responsibility of employers suddenly transferred onto workers. Most importantly for those who held on to their jobs, the share of corporate profits that they used to receive as salary or wages became accessible only through the stock market. Stock options were used as currency equivalents, replacing a portion of salary while minimizing drag on profits, since corporations did not have to report stock options as obligations on the balance sheet.

On the one hand, this was simply a massive shift of cash out of the pockets of workers and into those of shareholders. This produced dramatic increases in the value of American companies' stocks, so that workers with stock options and 401(k) plans often did better economically in the 1990s compared with the days before such innovations. On average, American stocks returned 18 percent annually during the 1990s-far above the historical average of 11 percent annual returns the U.S. markets had enjoyed since $1926 .{ }^{24}$ For the increasing percentage of Americans whose income and/or retirement depended on the stock market, the new financial risks they faced appeared to be well compensated by returns. But the dangers of this model became vividly apparent as the stock market declined-particularly following the collapse of Enron. Sixty percent of the 401(k) assets of Enron employees were held in company stock-shares which most Enron employees were forbidden from selling, even as the stock price plummeted and executives cashed out. ${ }^{25}$ 
The third trend pushing Americans into the stock market was the Clinton administration's 1997 revision of the tax code to favor investment income over wages and salary: the capital gains tax (which applies to profits from investments) was lowered to 20 percent, while the income of most investors was taxed in the 28 to 40 percent bracket. ${ }^{26}$ In the year following this change in the tax code, NAIC investment club enrollment hit its alltime high of 37,129 clubs.

The economic, technological, and legal trends driving investment club formation affected women disproportionately, which is one reason that so many participants in NAIC investment clubs are female-particularly women over the age of fifty. Women have been particularly hard-hit by changes in the pension system: both private pensions and Social Security benefits are determined by salary and years of continuous employment; since women make less than men for the same jobs, tend to be employed in lower-wage industries, and often have interrupted work histories, they get fewer benefits from both public and private retirement plans. ${ }^{27}$ Investing would appear to be a particularly attractive option for women, allowing them to compensate (at least potentially) for lower earnings and retirement security. But investing is expensive and out of reach for most women, given their income constraints and lack of exposure to investing opportunities. Thus, in addition to making investing affordable, NAIC investment clubs speak to a profound social need for investment education: Americans now bear a great deal more responsibility in managing their retirement finances, and require a great deal more investment knowledge, than previous generations.

\section{Investment Clubs as Formal Organizations}

It is important to note that the term "club" is somewhat misleading, in that investment clubs are quite different from associations that usually fall under that designation, such as book clubs or gourmet clubs. Though voluntary associations are often treated quite differently from other work groups in the scholarly literature, investment clubs are more similar to small businesses than to hobbyist groups. While some members of investment clubs may be interested primarily in the social contact offered by the groups-as are some members of corporate work groups, which appear more regularly in the research literature ${ }^{28}$ - the ostensible purpose of investment clubs is quite businesslike and utilitarian: to make money in the stock market. And while some individuals certainly participate in investment clubs as part of a generalized "thrill-seeking" orientation to the stock 
market, a substantial number are driven by the intense need faced by many Americans to provide their own financial safety net-particularly for retirement. ${ }^{29}$ Even those whose participation in investment clubs is driven more by social considerations than financial necessity must put their own money at risk and experience profits or losses that appear on their tax forms and in their bank accounts. In this sense, investment clubs are quite different from most other voluntary organizations: they can go broke, or even incur debts that members must bear.

Perhaps most importantly, no matter what an individual's motives for joining an investment club, he or she must submit to a degree of formalization, legal stricture, and hierarchy that, while common in work organizations, is not commonly associated with voluntary associations. In fact, investment clubs get the highest possible score on the "formalization index" used in surveys like the National Organizations Study to rate the degree to which command and control structures are in place to differentiate organizations from other collectivities; these include having a name for the group, as well as regular meetings governed by a stated purpose or goal, along with leaders and written rules, and a contract that members must sign. ${ }^{30}$ Typically, investment clubs meet every month for about two hours to decide which stocks to buy or sell using the money amassed from each member's contribution, averaging $\$ 35$ per person per month. The groups have hierarchical leadership structures, elect officers, make decisions jointly, and own assets (stocks) in common; new members pay an initiation fee, must sign a contract to join the club, and provide their Social Security numbers for the club's federal and state tax filings. ${ }^{31}$ Since they are financial partnerships, many investment clubs incorporate to protect members' assets and to facilitate compliance with the accounting rules that all clubs must observe by law. Thus, investment clubs, despite their name, are actually quite formal financial partnerships and, as a subject of study, can contribute to scholarly research in much the same way as other small businesses.

\section{Investment Clubs and the History of Speculative Manias}

During the 1990s, the usually staid Wall Street Journal declared that investing had become "America's most exuberant entertainment business." 32 This description hints at the place of the amateur investing boom and investment clubs within the long and colorful history of speculative manias-a history that was once famously summarized by John Kenneth Galbraith as "the mass escape from sanity by people in pursuit of profit." ${ }^{33}$ 
The notion of mass escape is crucial, and as such is well suited to sociological analysis.

Historically, speculative activities have been characterized by the breakdown of social boundaries; American investment clubs are very much of a piece with this tradition. Indeed, a cursory review of financial history reveals that the stock market boom of the late 1990s followed the classic pattern of speculative bubbles set by the Dutch tulip bulb craze of 1620 and the British South Sea Bubble of 1720. As financial historian Edward Chancellor has ably documented, speculative crazes unfold in three phases. ${ }^{34}$ First, an opportunity for profit arises, within an environment that encourages, or at least does not impede, speculation. Second, social and economic conventions are suspended, allowing the participation and possible enrichment of lower-status social groups. Finally, the process concludes with the bursting of the bubble and the allocation of blame and punishment. The ways in which investment clubs were viewed, by both participants and observers, followed this pattern with uncanny accuracy.

The beginnings of financial speculation have been traced to medieval Europe, where carnivals occasioned by Lent or other cultural events were among the rare social spaces in which economic activity for profit was sanctioned. Most significantly, shares in commercial ventures could be sold at such events, along with municipal bonds and lottery tickets. Later, financial bubbles were occasioned by innovations-whether driven by novelty, such as the fad in Holland for Turkish tulip bulbs, or necessity, such as the plan to nationalize the British government's debt through the issuing of shares in the South Sea Company. The populist investment boom of the 1990s could be described as a combination of novelty and necessity, driven in part by technological innovation (the World Wide Web and e-commerce, in particular) and in part by the need for many Americans to meet their financial needs privately, rather than relying on the government or their employers for a safety net.

Such events must occur within a relatively permissive atmosphere in order to precipitate a speculative mania. The Dutch and British not only possessed the great merchant empires of their time but also encouraged a freewheeling spirit of financial innovation, so it was no coincidence that they created the first two speculative crazes in history. While others developed many of the building blocks of modern capitalism—such as doubleentry bookkeeping and joint-stock companies-it was Dutch and British financiers who put the pieces together to support a network of global commerce. What the economist Joseph Schumpeter wrote of the South Sea Bubble was equally true of the stock market bubble of the late 1990s in the United States: "The mania of $1719-1720$. . was, exactly as were 
later manias of this kind, induced by a preceding period of innovation which transformed the economic structure and upset the preexisting structure of things." ${ }^{35}$

Among the most important structural conditions that facilitated the stock market boom of the 1990s was the ease with which individuals who were not finance professionals could form investment associations. The notion that anyone could start an investment club was popularized by the Beardstown Ladies, a group of rural Illinois women in their fifties, sixties, and seventies who collectively wrote three investment guides (based on NAIC principles) that ended up on the New York Times bestseller list. If these self-proclaimed financial neophytes could do it and succeed, the thinking went, anyone could. Their success built on the "anyone can invest" message of a previous bestseller, One Up on Wall Street, in which phenomenally successful mutual fund manager Peter Lynch outlined his "buy what you know" philosophy. Lynch wrote: "Twenty years in this business convinces me that any normal person using the customary three percent of the brain can pick stocks just as well, if not better, than the average Wall Street expert ... if you stay half-alert, you can pick the spectacular performers right from your place of business or out of the neighborhood shopping mall, and long before Wall Street discovers them." Lynch's evidence for this included his purchase of stock in the Limited, on the recommendation of his wife, who was impressed by the chain store during a trip to the mall. ${ }^{36}$

Supporting this populist message was a series of legal changes that further broke down barriers to investing, most notably the lowering of the capital gains tax and the repeal of the Glass-Steagall Act, which had separated securities brokerage from other branches of banking. The importance of a permissive legal and social atmosphere cannot be underestimated. As a counterexample, consider the case of Japan, in which the pooling of funds to buy stocks is forbidden without the purchase of a mutual fund license, which costs approximately U.S. $\$ 10$ million. This legal climate effectively outlaws investment clubs, and much of what Americans would regard as populist investing behavior. ${ }^{37}$

In another parallel to the South Sea Bubble, the speculative mania of the 1990s was fueled by copious amounts of coffee and dubious alliances between the public and private sectors. In 1720 London, most speculation was centered around coffeehouses: Jonathan's and Garroway's, in particular, became the favored meeting places for traders. Following the collapse of South Sea share prices in the fall of 1720, recrimination centered on members of Parliament and their perceived self-interest in creating the bubble: they not only floated the original idea of paying off the national 
debt with public stock issues, but profited handsomely from their insider information about the South Sea Company. Fast forward to the United States in the 1990s, where we find a boom fueled by designer coffee and presided over by a secretary of the treasury who was frequently described as the "ultimate Wall Street insider": Robert Rubin, who came to government after serving as co-chairman of Goldman Sachs. While Rubin himself was never accused of misconduct in that role, the corporate financial scandals of recent years are much like those of 1720, with their revelations about collusion among financial elites and the government officials charged with regulating their activities in the public interest.

In addition to the suspension of ordinary economic rules, a signal characteristic of the carnival atmosphere surrounding financial booms is the upheaval of social norms and institutions. Just as medieval carnivals challenged the authority of the church to assign moral meaning to economic activity, speculative bubbles throughout history have brought an anarchic spirit to bear on the status order and moral conventions. As Jonathan Swift lamented during the South Sea Bubble, "We have seen a great Part of the Nation's Money get into the hands of those, who by their Birth, Education and Merit, could pretend no higher than to wear our liveries." 38 During the 1990s, a slightly more positive spin was put on this sentiment, via the oft-heard refrain "Wall Street has become Main Street." While this was sometimes portrayed as a positive development, it was also true that as soon as the stock market hit a bumpy patch-as on October 27, 1997, which saw the largest single-day point drop ever in the Dow Jones Industrial Average-financial professionals came out in droves to blame the amateur investors who had entered the market in recent years. Ironically, it turned out that amateur investors were a major source of stability in the market following the crash of October 1997; it was the professionalsspecifically, pension fund managers-who were later shown to have done most of the panic selling. ${ }^{39}$

Class and gender roles have been shattered in every speculative mania. In 1720s Britain, stocks were one of the few forms of property that were not taxed and which even married women could own in their own name. The second subscription list for South Sea stock included the names of thirty-five women-40 percent of the eighty-eight subscribers. ${ }^{40} \mathrm{~A}$ kind of protoinvestment club even arose when a group of women rented a shop near Garroway's and Jonathan's coffeehouses-in a part of London that came to be known as Exchange Alley-where they drank tea and traded stocks. Several women of the period became quite wealthy in their own right as a result of financial speculation. Sarah, Duchess of Marlborough

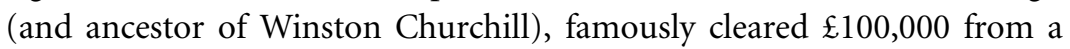


prescient sale of South Sea stock and as a result held the single largest share in the Bank of England. ${ }^{41}$ Later, in the speculative boom that followed the American Civil War, the Duchess of Marlborough's role was played by women like Victoria Woodhull, the "bewitching broker," and Hetty Green, the Quaker heiress who was known as the "Witch of Wall Street." Likewise, the protoinvestment club form arose again during this new speculative mania: "Clerks formed small clubs in order to pool their limited resources ... [and] in Saratoga, upstate New York, three young ladies set up a pool in Harlem stock and bought two thousand shares." ${ }^{42}$

Similarly, the 1990s witnessed the revival of group investing, particularly among women and people of modest means. The Beardstown Ladies' investment club, for example, was founded in part because the members could not get brokers to open accounts for them. As one member wrote, "brokerage houses were not particularly friendly places for women. There were few female brokers, and women, particularly older ones, were not considered desirable clients." ${ }^{43}$ The barriers to entry were partly financial and partly cultural: brokers expected not only that women would have less money to invest, and therefore less to offer in terms of commissions, but that women would make higher demands on them in terms of investment education. Investing involves a host of terms and concepts that can be daunting to those inexperienced with finance. That is why the presence of discount brokerage firms, such as Charles Schwab, did not solve the problems faced by novice investors: there was still an education gap.

Just as there was public outrage following other speculative manias, the end of the 1990s market boom left Americans looking for someone or something to blame and punish. The backlash begins with revulsion at the object of speculative mania: for example, following the crash of the tulip bulb market in 1620s Holland-a calamity that bankrupted many-a Dutch professor of botany was said to be so incensed by the sight of the plants that he would beat them savagely with his walking stick. ${ }^{44}$ Similar sentiments have been expressed by investors who lost money following the end of the U.S. stock market boom, although the objects of their frustrations were too elusive to be addressed via the walking stick method. Another common feature of postbubble social ritual is the punishment of elites. Like former head of the New York Stock Exchange Dick Grasso, and former Enron CEO Ken Lay following the collapse of the 1990s stock market bubble, business and government leaders who profited from speculative manias in the past were the objects of widespread public rage that sought to have them "pilloried, stripped of their wealth, and imprisoned." ${ }^{45}$ While such efforts were not always successful, they provided material for 
(C) Copyright, Princeton University Press. No part of this book may be distributed, posted, or reproduced in any form by digital or mechanical means without prior written permission of the publisher.

many a broadside, song, and pamphlet. Figure 1.2 shows one example: a playing card from a deck created in London immediately following the collapse of the South Sea Bubble. The card, like all the others in the set, depicts the folly of those who hoped to get rich(er) quick through purchasing stocks. The Six of Diamonds, shown here, depicts a woman lamenting her losses in the market, with the result that she "Pawn'd her fine Brocades, / And now appears like other homely Jades."

The use of humor remains to this day the primary form of social protest in the wake of financial scandal. For example, the travails of Martha Stewart have generated endless jokes, including a parody of her flagship magazine, titled Martha Stewart Living Behind Bars, which features a recipe for "jailhouse chili" and tips on how to decorate a prison cell. ${ }^{46}$ See figure 1.3 , which compares this to a similar image from a popular broadside created just after the South Sea Bubble, depicting a wealthy, bewigged Englishman languishing behind bars as a result of his financial malfeasance.

Figure 1.2

Six of Diamonds card from the South Sea deck (courtesy of Bancroft Collection, Baker Library, Harvard Business School)

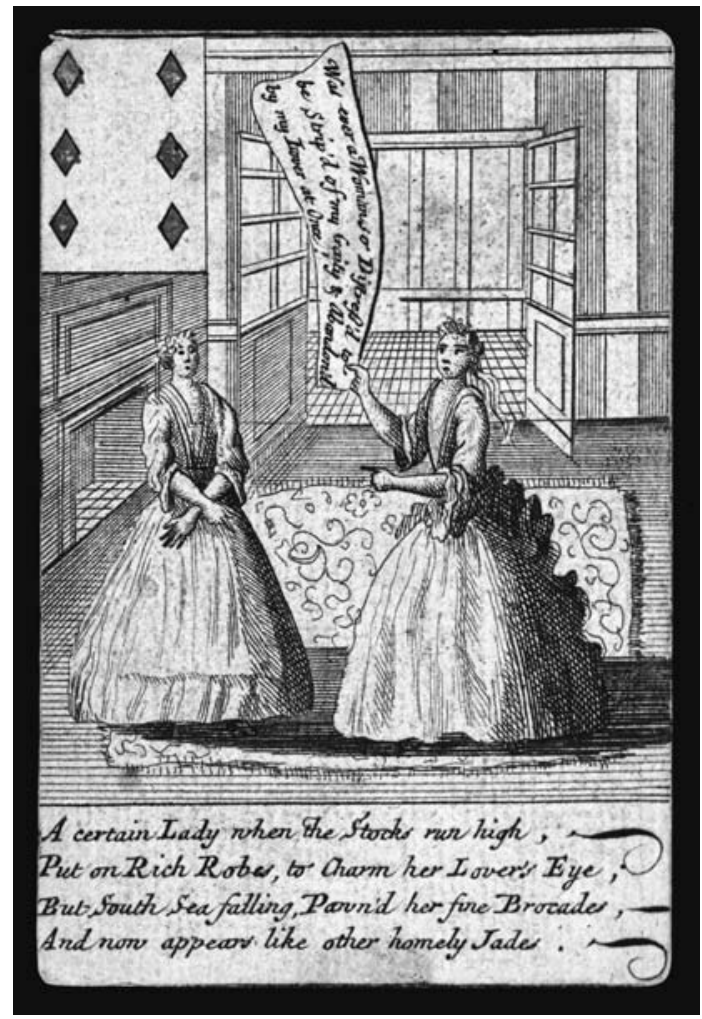


(C) Copyright, Princeton University Press. No part of this book may be distributed, posted, or reproduced in any form by digital or mechanical means without prior written permission of the publisher.

\section{MARTHA \\ STEWART}
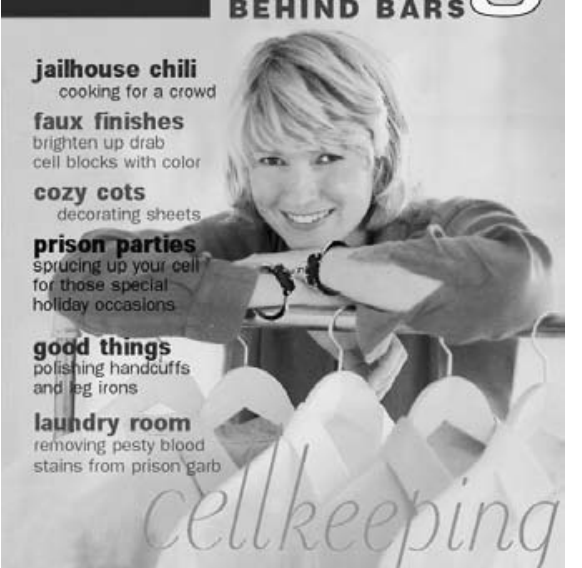

VOLUME 1 - NUMEEA 1 published is times s year for the
whmw.mathestewart con
Figure 1.3

Humor as social protest in two financial scandals (Bubbler's Medley, courtesy of Bancroft Collection, Baker Library, Harvard Business School)

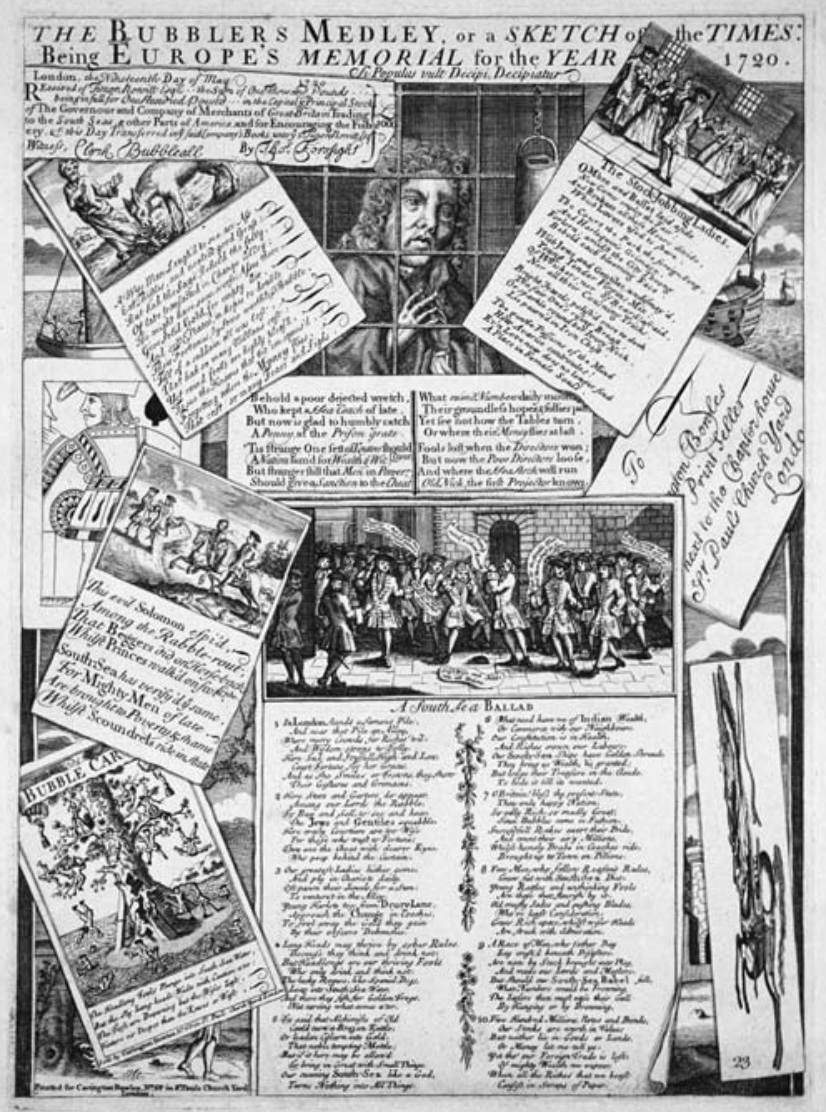


(c) Copyright, Princeton University Press. No part of this book may be distributed, posted, or reproduced in any form by digital or mechanical means without prior written permission of the publisher.

In an era of mass media, broadsides have been replaced by late-night talk shows, but the messages and motives are essentially unchanged, as the following examples suggest:

First Enron, then Tyco and now WorldCom. How come all these companies are off billions in their accounting and nothing ever happens to them? If you bounce a $\$ 15$ check at the Quickmart, the Feds are at your door! 一Jay Leno

This might be getting serious. The Securities and Exchange Commission is going to be investigating Vice President Dick Cheney. They'll begin that investigation as soon as Congress finishes investigating the Securities and Exchange Commission. —David Letterman

But by far the greatest recrimination has always been reserved for the "upstarts"- the ordinary people who breached the norms of class and gender to engage in financial speculation. The excoriation of the masses was illustrated in another card from the South Sea deck represented in figure 1.4.

Figure 1.4

Ten of Diamonds card from the South Sea deck (courtesy of Bancroft Collection, Baker Library, Harvard Business School)

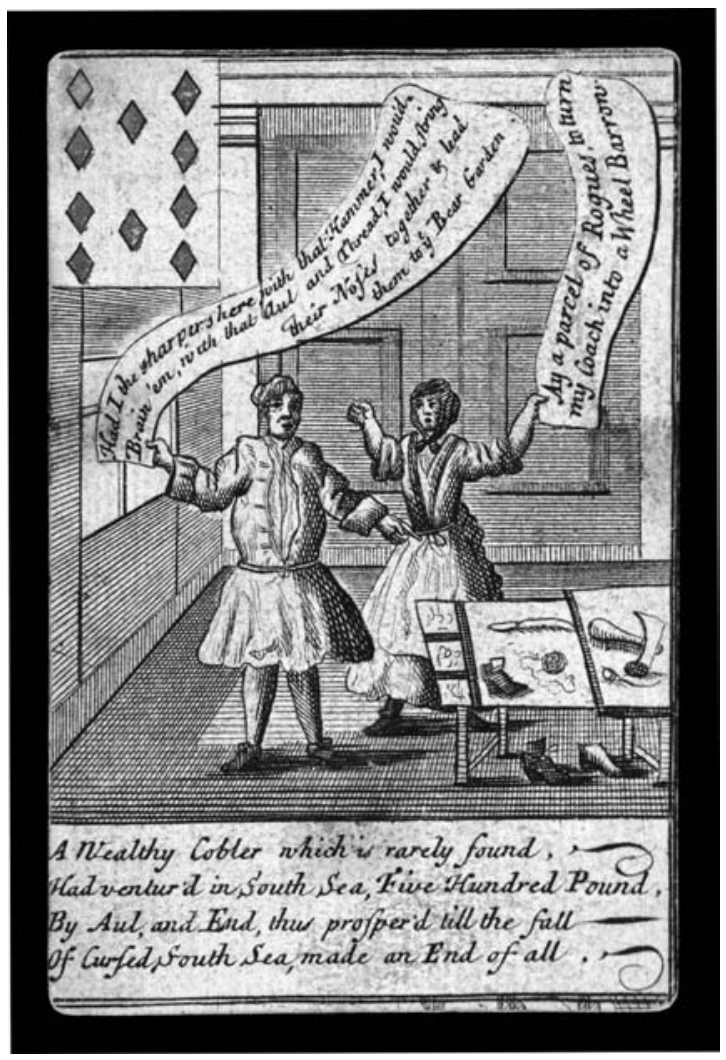


While the Six of Diamonds shows a noble lady brought low by the collapse of the South Sea Bubble, the Ten of Diamonds depicts the investment losses of a cobbler and his wife, with the following subscript:

A Wealthy Cobler which is rarely found, Had ventur'd in South Sea, Five Hundred Pound, By Aul, and End, thus prosper'd till the fall Of Cursed South Sea, made an End of all.

Economically empowered women have historically been favored targets for backlash. Following the collapse of the South Sea Bubble, numerous texts and works of visual art represented women investors in a degrading light, as gold diggers, harpies, and prostitutes. ${ }^{47}$ Several centuries earlier, the growing wealth and independence of women following the Black Death plague may have catalyzed the European witch craze of the Middle Ages, in which hundreds of thousands of women were burned at the stake. ${ }^{48}$ This precedent helps explain the extraordinary outpouring of schadenfreude that greeted the news that the Beardstown Ladies had overstated their portfolio returns. ${ }^{49}$ The headlines trumpeted "Debacle in Beardstown" 50 and, more colorfully, "Guru Grannies Caught Cooking the Books by the Money Men: Beardstown Ladies Exposed as Bumbling Amateurs." ${ }^{51}$ While no one accused the Beardstown Ladies of being "homely Jades," their virtue and intelligence were questioned in songs that bear a remarkable resemblance to those composed hundreds of years before. Consider, for example, the following excerpt from a song of 1720 titled "The Stock-Jobbing Ladies":

With Jews and Gentiles, undismay'd,

Young, tender Virgins mix;

Of whiskers, nor of Beards afraid,

Nor of all their cousening Tricks.

Bright Jewels, polish'd once to deck

The fair one's rising breast,

Or sparkle round her Ivory Neck,

Lye pawn'd in Iron Chest.

The genuine Passions of the mind

How avarice controuls!

Even Love does now no longer find

A place in Female Souls.

Compare this to two satirical songs published to celebrate the downfall of the Beardstown Ladies (both are set to the tune of "Camptown Ladies"): 
Beardstown Ladies sing this song, bushwah, bushwah

Beardstown stock tips mostly wrong, but the books sure paid. ${ }^{52}$

And

Beardstown Ladies sing this song,

Doo-dah, doo-dah,

Ladies got their numbers wrong,

All the doo-dah day.

Thought they'd seen the light,

Thought they'd found the way,

Trust your money to the amateurs,

Somebody's going to pay. ${ }^{53}$

Artifacts such as these suggest that little about the "new economy" stock boom of the 1990s was actually new. In historical perspective, the United States during the late 1990s looks a lot like seventeenth- and eighteenthcentury Europe during similar periods of speculative mania. The great bull market can be envisioned as a scaled-up version of the medieval carnivals, with the big tent located in the Silicon Valley. This particular carnival was precipitated by a number of events, including the high-tech revolution, the easing of legal regulations on investing, and the growing need to provide one's own retirement funding in an uncertain climate of $401(\mathrm{k})$ plans and an underfunded Social Security plan. The subsequent collapse of the bubble-known in the Silicon Valley as the "dot.bomb" period-not only brought about the downfall of corporate leaders but also played into the recall of California governor Gray Davis. Davis presided over the tail end of the bubble, and his historically unprecedented ouster from office can be regarded as part of the ritual cleansing that follows a mass financial debauch. His replacement by Arnold Schwarzenegger-famous for stalking through postindustrial wastelands as the Terminator-is a fitting emblem of the postapocalyptic, postboom economy.

\section{Investment Clubs and Economic Sociology}

This chapter has attempted to contextualize investment clubs not only in the social, economic, legal, and technological conditions of the 1990s, when this study was conducted, but also within the larger framework of financial history. The historical perspective suggests that investment clubs are not a fad but part of a recurrent social response to new economic opportunities and demands. Further, the increasing ability to conduct transactions in the absence of physical contact does not threaten face-to-face groups like 
investment clubs with obsolescence; on the contrary, "as more information flows through networked connectivity, the more important become the kinds of interactions grounded in a physical locale"-a phenomenon known as "Castells' paradox." ${ }^{54}$ In other words, Castells suggests that faceto-face settings for transactions will be accorded increasing value by market participants as machine-mediated interaction becomes more common.

Thus, in addition to their empirical significance as part of the economic and cultural history of capitalism in the United States, investment clubs are poised to grow in both scope and influence. For scholars, they provide insight not only into the ramifications of Castells' paradox but also into other questions of great import to economic sociology, such as how value is socially constructed, who is empowered to participate in this social construction, and how microsocial factors such as these aggregate to the level of macrosocial institutions like the stock market. Chapter 2 will address these issues in greater detail.

\section{APPENDIX}

\section{Data Sources for This Study}

Sample selection for this study began in May 1997 with an effort to contact as many investment clubs as possible within the San Francisco Bay Area, where I was based at the time. My objective was to gain rapid familiarity with the issues, themes, and practices common to the clubs. These contacts were made in three ways: through local NAIC officials, who invited me to their clubs; through cold-calls to a list of Bay Area clubs provided by NAIC national headquarters; and through an NAIC investment seminar at which I was allowed to make a brief presentation on my project. Of the three methods, cold-calling yielded the greatest number of successful contacts: half the clubs in the final sample were recruited in that way. Though many club officers were a bit dubious at first about allowing me to observe their meetings for a year, I was refused only two times out of dozens of calls. And once I was able to attend a club meeting, introduce myself, and explain my purpose, there was never any dissent-including instances where I was asked to leave while the members took a vote on whether to allow me to return.

In this effort I benefited enormously from NAIC's long-standing practice of encouraging outside observers to attend club meetings. Since the clubs are designed to be learning organizations, one of their official functions is to "evangelize" for the cause of stock market investing. They fulfill this role by allowing nonmembers to sit in on meetings. Often, this is a prerequisite for membership. Members are also encouraged to visit and 
learn from other clubs. As a result, most clubs are used to, or at least prepared for, strangers attending their meetings. The only difference in this case was my request to stay for a longer period of time than usual. The decision to observe ten meetings of each club was somewhat arbitrary, but made with an eye toward being around long enough to understand the unique dynamics of each group, and to monitor its responses to changes in the stock market. The market cooperated by racking up both record losses and record gains over the observation period.

The sample I selected was designed to provide insight into as broad a spectrum of investors as possible while remaining a manageable size for steady, long-term observation. Thus, the sample includes clubs of varying gender composition (all-male, all-female, and mixed), clubs that were brand-new as well as those that had been in business for more than forty years, composed of young people and the elderly, as well as a variety of racio-ethnic groups, occupational groups, marital statuses, and sexual orientations. Finally, I sought variation in performance, including clubs that had earned substantial profits on their investments and those that had limped along, even during a rising market. The average investment club in the United States earned an annualized rate of return of approximately 12.6 percent on their portfolios since inception; while this was somewhat above the historical average return of the U.S. stock market over the past century, it was low for the late 1990s, in which annualized rates of return for the market indexes regularly exceeded 30 percent.

The seven clubs in my observational sample-whose names, along with those of their members, have been changed to protect their privacyincluded:

- Portfolio Associates, an all-men's club in continuous operation for forty-one years. It had eighteen members and was a very high performer with a 38 percent rate of return on its portfolio since inception; the club's total portfolio value had just surpassed the $\$ 1$ million mark when I began attending meetings.

- Bulls \& Bears, a five-year-old mixed club composed of six men and four women who were all employed by a major defense contractor. The club was a high performer, with a 23 percent rate of return on its portfolio since inception.

- Ladies with Leverage, a three-year-old club made up of fourteen women who had met through volunteer activities in a wealthy Silicon Valley suburb. The club was a low performer compared to others in the sample, with an 11.5 percent rate of return on its portfolio since inception. 
- California Investors, a six-year-old club composed of fourteen men who had all been colleagues in the insurance industry and had recently retired. The club was an average performer, with a 12.6 percent rate of return since inception.

- Asset Accumulators, a five-year-old club composed of sixteen women, all former schoolteachers, who had met through membership in the American Association of University Women. The club had earned a whopping 36.5 percent rate of return on its portfolio since inception.

- Educating Singles Against Poverty, a three-year-old club composed of nine women and three men who had met through a church singles group. The club was a low performer, with a 9.4 percent rate of return on its portfolio since inception.

- Valley Gay Men's Investment Club, a newly formed club composed of men who had met through a classified ad placed in a local gay community newspaper. The group did not buy any stocks until five months into my observation period, providing too little data to calculate a meaningful rate of return. Nevertheless, observing this group allowed me to witness the process by which first-time investors orient themselves to the market.

Data gathering during this phase of the study took several forms, including taking verbatim notes of the group discussions, which were transcribed within twenty-four hours of the meetings. I tape-recorded the meetings in five of the seven clubs; as to the others, members of one of the men's groups objected to being taped, and recording devices were not permitted on the military base where one of the mixed clubs met. During the meetings, I kept track of data such as:

- Proportion of total meeting time devoted to stock selection, as opposed to social conversation or procedural issues (e.g., catching up on each others' family news and vacation plans, or interpretation and modification of bylaws). I started using a stopwatch to track this issue after I noticed that the low-performing clubs seemed to be spending very little of their meeting time on stocks.

- Stock presentations: who made them, where the presenters got their ideas, what kinds of evidence were presented, and what actions were taken.

- Voting: who made the motion to buy or sell, who seconded it, who voted for and against, who abstained.

- Artifacts: all handouts distributed at the meetings-accounting statements, agendas, and so on-plus background documents, such as the club's partnership agreement. 
In addition, I gathered information about club history and members' backgrounds in two ways. First, each of the clubs in the sample pretested the survey I designed for the quantitative part of the study (they did not participate in the final survey project, however). This allowed me to gather a great deal of demographic data about members, including age, income, education, and personal investing habits. Second, I scheduled in-depth interviews with "core" club members-usually the current and past officers-to discuss the club's history in terms of formation, membership, philosophy, and investment choices. In preparation for this meeting, I reviewed each club's minutes and accounting statements (as well as any other printed material) all the way back to its inception, in order to ask more informed questions. I found that "the most reliable indicator of my impressions was saturation-the fact that after a certain amount of interviewing I began to be able to predict the tenor and directions our conversations would take." ${ }^{25}$

Throughout the study, I analyzed the transcripts of club meetings and interviews to detect major themes; my strategy focused on uncovering patterns in interactions, decision processes, and mental maps. I used these themes as a point of departure for an iterative process-moving back and forth between the data and an emerging conceptual structure-to describe how amateur investors understood and made decisions within the stock market. I also used my findings to develop questions for a survey that was mailed to three thousand NAIC investment clubs across the United States in January 1998.

I selected the sample for the national survey by starting from a random entry in the NAIC membership database and choosing every tenth club name until the list included three thousand names-a little less than 10 percent of the NAIC membership at the time. Each club received a packet containing two survey instruments: one designed to glean group-level information, and fifteen copies of a second survey designed to gather data from individual club members. The group-level survey was to be filled out by the club's president; the four-page instrument included thirty multiplechoice and fill-in-the-blank questions about club performance, composition, and organizational structure. The presidents were instructed to hand out the individual-level surveys at the next meeting, allowing the members time to fill out the four-page instrument (which included thirty-one multiple-choice and Likert-style questions about their demographic background and investing behavior, both inside and outside the club); the presidents were then asked to return both the club-level and individual-level surveys to NAIC in a postage-paid envelope. The individual-level surveys were all anonymous, and no identifying information about individual members 
was requested in the club-level survey. The only names and addresses given were those of the club presidents, which were listed in NAIC's database already as part of the club registration process.

This project netted a total of 1,279 usable responses from clubs, a response rate of 43 percent. The average club responding to this survey was 4.3 years old $($ s.d. $=6.4$ ) and owned a portfolio of stocks worth $\$ 43,000$ (s.d. $=\$ 7,300)$; on average, each club had 15 members $($ s.d. $=5$ ). At the individual level, a total of 11,369 members responded to the survey, including 7,162 (63 percent) women and 4,207 (37 percent) men. The average rate of within-group individual participation in the study was 70 percent of the membership (s.d. $=.18$ ). The average member was between 45 and 50 years old $($ s.d. $=12.4)$, college educated, had an income of $\$ 58,000$ $($ s.d. $=\$ 13,000), 11$ years of investing experience $($ s.d. $=6.6)$, and had belonged to the club since its inception. While it was not possible to compare the sample frame for this study with the entire population of investment clubs, analysis of the nonresponding clubs indicated no difference in terms of composition, size, age, or portfolio value from clubs that did participate in the survey.

Please see section two of the book for details on specific measures and analytical techniques, as well as the additional data gathering and analyses I conducted to test the representativeness and validity of this survey sample. 